\title{
Violence as a main symptom of schizophrenia and expressed emotion in relatives of users from Instituto Jalisciense de Salud Mental
}

\author{
Ricardo Ignacio Audiffred Jaramillo, 'Javier Eduardo García de Alba García, ${ }^{2}$ Ivonne García Monzón, \\ Carlos Isaac Loza Salazar, ' Leticia Limón Cervantes ${ }^{3}$
}

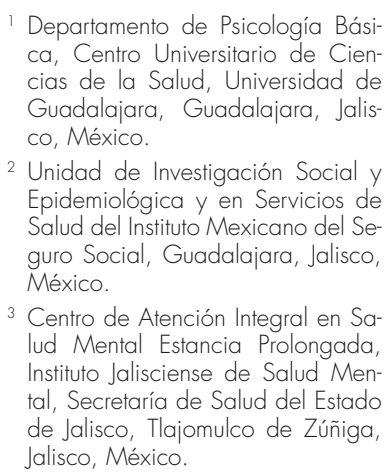

Departamento de Psicología Bási$\mathrm{ca}$, Centro Universitario de Ciencias de la Salud, Universidad de Guadalajara, Guadalajara, Jalisco, México.

2 Unidad de Investigación Social y Epidemiológica y en Servicios de Salud del Instituto Mexicano del Seguro Social, Guadalajara, Jalisco, México.

3 Centro de Atención Integral en Salud Mental Estancia Prolongada Instituto Jalisciense de Salud Mental, Secretaría de Salud del Estado de Jalisco, Tlajomulco de Zúñiga, Jalisco, México.

\section{Correspondence:}

Ricardo Ignacio Audiffred Jaramillo Departamento de Psicología Básica, Centro Universitario de Ciencias de la Salud, Universidad de Guadalajara. Calle Sierra Mojada 950, puerta 19 Col. Independencia, C.P. 44340 Guadalajara, Jalisco, México. Phone: 33 1058-5200, ext. 33946 Email: ricardo.audiffred@ academicos.udg. mx

Received: 13 October 2020 Accepted: 26 January 2021

Citation:

Audiffred Jaramillo, R. I., García de Alba García, J. E., García Monzón, I., Loza Salazar, C. I., \& Limón Cervantes, L. (2021). Violence as a main symptom of schizophrenia and expressed emotion in relatives of users from Instituto Jalisciense de Salud Mental. Salud Mental, 44(6), 277-285

DOI: $10.17711 /$ SM.0185-3325.2021.036

\begin{abstract}
Introduction. Schizophrenia is a mental disorder that affects 21 million people worldwide, and it brings about environments with high Expressed Emotion (EE) in the families of these individuals. High EE is characterized by negative evaluations, criticism, and overinvolvement of family members towards the person with schizophrenia. Objective. Recognize the relationship between the cultural agreement about the symptoms of schizophrenia and EE. Method. The study had a mixed design, with a cognitive anthropology method. The sample had a probabilistic estimate based on Weller and Romney proposal, with a competence higher than $50 \%$, a confidence level of $95 \%$, and $5 \%$ of type I error. The 40 participants were selected with a simple randomized probability sampling, conformed by relatives of patients from the Instituto Jalisciense de Salud Mental (SALME). Results. The $45 \%$ of the sample showed a high EE according to the Questionnaire for Measuring the Level of Expressed Emotion (CEEE). A single valid cultural model with statistical significance was found, in which violence was identified as the main symptom of schizophrenia. The best-informed relatives showed a lower EE (Mann-Whitney $U=1,000, p<.001$ ). Discussion and conclusion. Schizophrenia disorder has been associated with stigmas that generate rejection and fear. A total of $40 \%$ of the world's population believe people with schizophrenia are dangerous and violent. It must be considered opportune to reconsider the use of the term "schizophrenia", which is etymologically imprecise and supports stigmas that have excluded and defamed people with schizophrenia for more than a century.
\end{abstract}

Keywords: Schizophrenia, expressed emotion, violence, cultural agreements, mental health, CEEE.

\section{RESUMEN}

Introducción. La esquizofrenia es un trastorno mental que afecta a 21 millones de personas en el mundo, y propicia ambientes con una Emoción Expresada (EE) alta en los hogares de estos individuos. La EE alta se caracteriza por evaluaciones negativas, criticismo, control y sobreinvolucramiento de los familiares hacia la persona con esquizofrenia. Objetivo. Conocer la relación entre el acuerdo cultural sobre los síntomas de la esquizofrenia y la EE. Método. El diseño fue mixto, con un método antropológico para estudios de antropología cognitiva. La muestra tuvo un cálculo probabilístico basado en Weller y Romney con una competencia mayor al $50 \%$, un nivel de confianza de $95 \%$ y de error del $5 \%$. Se seleccionaron 40 personas, con un muestreo probabilístico simple aleatorizado; todas ellas eran familiares de usuarios del Instituto Jalisciense de Salud Mental (SALME). Resultados. El $45 \%$ evidenció una EE alta según el cuestionario-encuesta evaluación del nivel de emoción expresada (CEEE). Se encontró un único modelo cultural válido con significancia estadística, en el cual la violencia fue identificada como el síntoma principal de la esquizofrenia. Los familiares mejor informados mostraron una menor EE $(U$ de Mann-Whitney $=1.000, p<.001)$. Discusión y conclusión. La esquizofrenia se ha asociado con estigmas que generan rechazo y miedo hacia quienes la padecen. El $40 \%$ de la población mundial considera que las personas con esquizofrenia son peligrosas o violentas. Debe considerarse oportuno replantear el uso término "esquizofrenia", el cual etimológicamente es impreciso, y sostiene estigmas que excluyen y difaman a las personas con esquizofrenia desde hace más de un siglo.

Palabras clave: Esquizofrenia, emoción expresada, violencia, acuerdos culturales, salud mental, CEEE. 


\section{INTRODUCTION}

Schizophrenia is a chronic, serious, and disabling mental disorder that affects almost 21 million people (WHO, 2019). Its worldwide prevalence is estimated between .5 and $1 \%$. The incidence of this illness is up to 40 new cases per 100,000 people per year (APM, 2014). In addition, it represents $50 \%$ of psychiatric hospitalizations (APM, 2014). This mental disease is one of the most important causes of loss of disability-adjusted life years (DALYs), which amount to 2,000 days per million people per year. The costs of this illness are estimated to be close to seven million dollars a year per million inhabitants according to Gutiérrez (2011), which represent an approximate annual cost of 882 million dollars per year in Mexico.

Schizophrenia has been classified as one of the disorders that causes the most difficulties for mental health specialists (Rosas-Santiago, 2016), due to its alterations in areas such as: thinking, perception, affection, language, behavior, and general functionality. The main symptoms of this disease described by the World Health Organization (WHO) in the International Statistical Classification of Diseases and Related Health Problems (ICD-10) and the American Psychiatric Association (APA) in the Diagnostic and Statistical Manual of Mental Disorders (DSM-5) are: hallucinations, which are conceived as abnormal perceptions; delusions, understood as unalterable irrational beliefs; and disorganized language. In addition, disorganized behavior and negative symptoms are noted as important symptoms.

Furthermore, schizophrenia is an illness that engenders many complications for primary caregivers, who in different studies have shown elevated levels of emotional, physical, and financial overload, a situation that interferes with their psychological well-being (De la Higuera, 2005). Emotional overload causes high levels of stress in families, which promotes environments with high expressed emotion (EE) in homes. High EE is characterized by the relationships and communications that permeate the family atmosphere. This is often loaded with negative evaluations, criticism, control, and over-involvement. Such a dynamics causes in individuals with schizophrenia a deterioration of self-concept, poor adherence to treatment, negative emotional behaviors, symptomatic exacerbations and continuous relapses (Rosenfarb, Nuechterlein, Goldstein, \& Subotnik, 2000; Barrowclough et al., 2003; Sellwood, Tarrier, Quinn, \& Barrowclough, 2003), cited by De la Higuera (2005).

Negative attitudes of family members, distinctive of high EE, are the consequence of ignorance and a series of prejudices according to Ochoa et al. (2011). These stereotypes embrace ideas that individuals diagnosed with schizophrenia are aggressive, unpredictable, lazy, unproductive, weird, irrational, and hence guilty of their disorder. These assumptions stem from the internalization of negative perceptions of society about mental illness and stigma (Phillips,
Pearson, Li, Xu, \& Yang, 2002). Beliefs influence attitudes and predispose people to react in a certain way, sometimes wrong, as part of a causal chain of behavior (García-Sílberman, 2002).

Anthropology is a scientific discipline that studies the production of knowledge about the cultural realities of various populations, and is applied to gain an in-depth understanding of different fields and numerous objects of study (Schaffhauser, 2010). The specialized area of this science is known as cognitive anthropology. This scientific discipline, as Herrera-Suárez et al. (2008) argue, studies the cultural representations of different social groups on issues associated with health-disease.

The perspective of cultural representations of Moscovici, Jodelet, Romney, Welles, and Batchelder, according to García de Alba-García, Quintanilla-Montoya, Sánchez-Loyo, Morfín-López, and Cruz-Gaitán (2011), is one of the theories that grants the understanding of symbolic structures that guide people behavior about how mental health is understood. The importance of recognizing which is the cultural agreement of people involved with chronic diseases has been highlighted in various studies (García de Alba-García, Salcedo-Rocha, Hayes, \& Milke, 2015). Previous research, such as Jenkins (1991), have mentioned the impact of EE on the course of schizophrenia and cultural meanings of respect and dignity, as main elements for the maintenance of family functioning and cohesion as a support group. Therefore, in this study it was considered essential, as a main objective, to recognize the relationship between the cultural agreement about the symptoms of schizophrenia and EE.

\section{METHOD}

This research used the methods of cognitive anthropological studies to analyze through the cultural agreement, as a main objective, how the relatives of individuals with schizophrenia understand the symptoms of this disorder. A secondary objective is to enquire about the relation between high $\mathrm{EE}$ and the understanding of these symptoms.

\section{Design of the study}

The study had a mixed design with a cognitive anthropology method.

\section{Subjects / description of the sample}

This study included relatives of patients diagnosed with schizophrenia from SALME, and had a probability sampling method, with a simple random sampling technique (SRS). The sample was calculated based on Weller and Romney (1998) proposal for cognitive anthropological 
studies, with a competence higher than $50 \%$, a confidence level of $95 \%$, and $5 \%$ of type I error. The sample size consisted of 40 people from 18 different families.

\section{Locations}

The study was carried out at SALME, of Secretaría de Salud del Estado de Jalisco whom lived on the Área Metropolitana de Guadalajara (AMG), from the State of Jalisco, México.

\section{Measurements}

The ICD-10 was used for the confirmation of schizophrenia diagnosis through the Mini International Neuropsychiatric Interview (MINI) (Heinze, Sheehan, \& Cortés, 2000). To evaluate the EE, the instrument CEEE created by Guanilo and Seclén (1993) was used. This instrument is a structured Likert-scale questionnaire with 30 items that measure criticism, overinvolvement, and hostility, which was adapted for the Mexican population with an $>.857$ alpha of Cronbach. The validation was made by Rascón, Gutiérrez, Valencia, and Murow (2008) with the Five-Minute Speech Simple interview (FMSS), obtaining Kappa results of: CRI: .753 and SIE: .729 .

The cultural agreement was determined with the free list technique (Fleisher \& Harrington, 1998) applied to each of the participants on the symptoms of schizophrenia in order to obtain the semantic model of the cultural agreement. Anthropac software ${ }^{\circledR}$ (Borgatti, 1994) was used to analyze the ratio between the variances for the cultural agreement model; in this case, on the main symptoms of schizophrenia. The validation of a cultural agreement was considered only when the variability ratio was equal or greater than three (Borgatti, 1994). The average of cultural knowledge was used as a correlation with values ranging from 0 to 1 . Johnson's cultural assembling was used to integrate the similar items and to elaborate the graphs of virtual distances on a multidimensional scale, with a stress adjustment between all the items less than .100 (Clark, Vojir, Hester, Foster, \& Miller, 1998). With the support of this program, good informants (people with adequate cultural competence) and bad informants (people with inadequate cultural competence) were categorized based on the degree of group knowledge in correlation with the consensus model.

\section{Procedures}

The relatives of people with a diagnosis of schizophrenia confirmed with the MINI were located by telephone and appointments were scheduled at their homes. All those who were identified as primary caregivers of the person with schizophrenia were included and a consent form was signed. The collection of sociodemographic data (gender, civil sta- tus, occupation, scholarship, and familiarity) was carried out through the use of a card to record the information of the patient's families. Then, based on the cognitive anthropological method, the free lists technique of Fleisher and Harrington (1998) was used to identify how the familiars of people with schizophrenia comprehended the symptoms of this mental disease. The free list technique recollected the understanding of contestants by a single researcher, in a place with privacy at people's homes in a first visit. On a second visit, the CEEE and the pile sorting technique (Ross, 1998) were applied. Anthropac software ${ }^{\circledR}$ (Borgatti, 1994) was used to establish the cultural agreement model. The Statistical Package for the Social Sciences 20 (SPSS 20) was used to perform parametric and non-parametric statistical calculations.

\section{Statistical analyses}

The absolute and relative frequencies, proportions, central trend measures (mean) and dispersion measures (standard deviation) were calculated with the appropriate measurement scales. The relation between qualitative (cultural knowledge), and quantitative (EE) variables were performed using parametric tests (T-test, one-factor ANOVA) and non-parametric tests (Fisher's $\mathrm{X}^{2}$ tests, Mann-Whitney U) with a $95 \%$ confidence level and an alpha error of $5 \%$, with the SPSS 20 program. Normality tests were performed (Kolmogorov-Smirnov or Shapiro-Wilk), Anthropac software ${ }^{\circledR}$ (Borgatti, 1994) was used to analyze the ratio between the variances of the cultural agreement model for the main symptoms of schizophrenia and to elaborate the graphs of virtual distances on a multidimensional scale.

\section{Ethical considerations}

This study was conducted in accordance with the ethical principles for research on Helsinki's human rights declaration, the International Conference on Harmonization for Good Medical Practices and the Ley General de Salud en Materia de Investigación para la Salud de los Estados Unidos Mexicanos. The ethical aspects of this document established general guidelines and principles of the Reglamento de la Ley General de Salud en Materia de Investigación para la Salud refer to (Secretaría de Salud, 1987), complying with articles 13 and 14 (fraction I, II, III, IV, V, VII, VIII) of TITLE TWO corresponding to the ethical aspects of research in human beings. This research, having a descriptive methodology, was considered as a research with minimal risk based on the Ley General de Salud en Materia de Investigación para la Salud.

Therefore, the signing of an informed consent letter was requested for the study participants, two witnesses, and the principal study investigator. This research was submitted for consideration and accepted to be carried out by the 
Table 1

Sociodemographic data

\begin{tabular}{lrrlrr}
\hline Variable & Frecuency & $\%$ & Variable & Frecuency & $\%$ \\
\hline Gender & & & Occupation & & \\
Male & 8 & 20 & Housekeepers & 11 & 27.5 \\
Woman & 32 & 80 & Employed & 12 & 30.0 \\
$\quad$ Total & 40 & 100 & Self-employed & 11 & 27.5 \\
Civil status & & & Unemployed & 3 & 7.5 \\
Single & 8 & 20 & Student & 3 & 7.5 \\
Married & 24 & 60 & Total & 40 & 100.0 \\
Free union & 1 & 2.5 & Familiarity & & \\
Separated & 2 & 5 & Mother & 7 & 17.5 \\
Divorced & 1 & 2.5 & Father & 3 & 7.5 \\
Widowhood & 4 & 10 & Sibling & 19 & 47.5 \\
$\quad$ Total & 40 & 100 & Sisters-in-law & 2 & 5.0 \\
Scholarship & & & Cousins & 2 & 5.0 \\
$\quad$ Elementary & 16 & 40 & Nephews & 4 & 10.0 \\
Middle & 10 & 25 & Wife & 1 & 2.5 \\
High & 4 & 10 & Uncles & 2 & 5.0 \\
$\quad$ Degree & 6 & 15 & Total & 40 & 100.0 \\
No education & 4 & 10 & & & \\
Total & 40 & 100 & & & \\
\hline
\end{tabular}

Research Committee of the UISESS-IMSS and the Bioethics and Research Committee of SALME with registration number 186.

\section{RESULTS}

The sample of the present study was composed by 40 relatives of people with schizophrenia from 18 different families of the AMG. The average age of the participants was 48.5 years (18-86), and $80 \%$ were women. The marital status of the individuals was $60 \%$. Forty percent had elementary studies, $25 \%$ had completed middle school, $15 \%$ had some degree, and the rest had high school or no education $(20 \%)$. Occupational statistics showed an equal percentage of $27.5 \%$ between those who were self-employed and those who were housekeepers. Seventeen point five percent had formal jobs, while the rest were unemployed or students (55\%).

In total, seven were mothers, three fathers, 19 siblings, two sisters-in-law, two cousins, four nephews, one wife, and two aunts. Thirty-five percent identified their selves with a low socioeconomic status, 35\% low status and 25\% part of a middle-class. Of all caregivers, 55\% reported having a good relationship with their family members diagnosed with schizophrenia, while $30 \%$ considered their relationship as normal. The rest expressed having bad relationships with their relatives $(15 \%)$ as shown in Table 1 .

Of the total number of participants, based on the CEEE, 45\% showed a high expressed emotion, and 55\% showed a low expressed emotion. For this classification, the cut-off point referred by De la Torre Vera (2018) was taken, in which a score of 30 to 64 was considered low expressed emotion and 65 to 120, high expressed emotion (Table 2).

Based on the one-way ANOVA, there was no significant difference between gender $(p=.898)$, marital status $(p=.839)$, religion $(p=.473)$, education $(p=.382)$, occupation $(p=.479)$, or type of familiarity $(p=.170)$, with either high or low emotion expressed. Only with Fisher's chi square it was possible to prove that those who live with people with schizophrenia show significantly a higher EE $\left(\mathrm{x}^{2}=4.82, p=.05\right)$ compared to those who did not live with them.

Table 2

Subjects with expressed emotion

\begin{tabular}{|c|c|c|c|c|}
\hline Subjects & Frecuency & $\begin{array}{l}\text { Average scores } \\
\text { of expressed } \\
\text { emotion }\end{array}$ & $\begin{array}{l}\text { Expressed } \\
\text { emotion } \\
\text { High/Low }\end{array}$ & $\%$ \\
\hline $\begin{array}{l}1,3,5,7,8,9,12,13,15,17,21,27,28 \\
31,32,34,37,39\end{array}$ & 18 & 97.8 & High & 45 \\
\hline $\begin{array}{l}2,4,6,10,11,14,16,18,19,20,22,23 \\
24,25,26,29,30,33,35,36,38,40\end{array}$ & 22 & 47.7 & Low & 55 \\
\hline Total & 40 & & & 100 \\
\hline
\end{tabular}


Table 3

Model of the cultural agreement on symptoms

\begin{tabular}{clcc}
\hline Rank & Item & Frecuency & $\%$ \\
\hline 1 & Violence & 16 & 12 \\
2 & Auditory hallucinations & 15 & 11 \\
3 & Anger & 11 & 8 \\
4 & Visual hallucinations & 9 & 6 \\
4 & Emotional disorders & 9 & 6 \\
4 & Lost of reality & 9 & 6 \\
5 & Intolerance & 8 & 5 \\
6 & Fear & 5 & 3 \\
7 & Uncleanness & 4 & 2 \\
7 & Delusions & 4 & 2 \\
8 & Rest & 55 & 39 \\
& Total & 136 & 100 \\
\hline Cultural agreement measuring & & \\
\hline Model & Variance & $\%$ & Probability ratio \\
\hline 1 & 31.211 & 96.0 & 38.562 \\
2 & .809 & 2.5 & 1.673 \\
3 & .484 & 1.5 & \\
Total & 32.504 & 100 &
\end{tabular}

Regarding the manifestations that were considered by relatives as symptoms of schizophrenia, the people who participated in this study identified violence $(12 \%)$ as the main symptom of this condition, in addition to anger (8\%) and intolerance $(5 \%)$. Auditory hallucinations ranked second $(11 \%)$, and visual hallucinations ranked fourth $(6 \%)$ along with loss of reality $(6 \%)$. Delusions were not mentioned as one of the most relevant symptoms and were found in the same place as uncleanness $(2 \%)$, the only sign mentioned that is associated with negative symptoms. Of those mentions by family members, a single valid cultural model was found, with a variability ratio of 38.56, and a statistical significance lower than $(p<.001)$, which included $96 \%$ of all the possible variations of the model items. This can be seen in Table 3.

In addition, a multidimensional diagram was found with a stress adjustment of .010, represented in Figure 1.

In relation to the information provided by the participants, with the support of the Anthropac program, good informants (people with adequate cultural competence) and bad informants (people with inadequate cultural competence) were categorized based on the degree of group knowledge in correlation with the consensus model. All the subjects classified with adequate cultural competence obtained results of a low EE and the people with inadequate cultural competence showed a high EE as can be seen in Table 4.

The T-test was applied for independent samples in order to find if there was a significant difference in the expressed emotion between people who had adequate cultural competence and those who had inadequate cultural competence. Comparison of the variances of both groups resulted in a statistical significance of $t=-9.15(p<.001)$, data confirmed by the confidence interval $(95 \%, \mathrm{CI}[-64.51,-40.67])$. In order to validate the use of the t-test, the goodness of fit was considered to prove the normality and homogeneity of both groups. The Levene test indicated in Table 4 showed a level of significance greater than $.05(p=.090)$, for which it could be assumed that the sample showed homogeneity of its variances. The normality based on the Shapiro-Wilk test (the Kolmogórov-Smirnov test was discarded because the groups were less than 50 subjects), the results of both groups were significant.

Due to this positive asymmetry in both groups, and based on the idea that the null hypothesis is equal to nor-

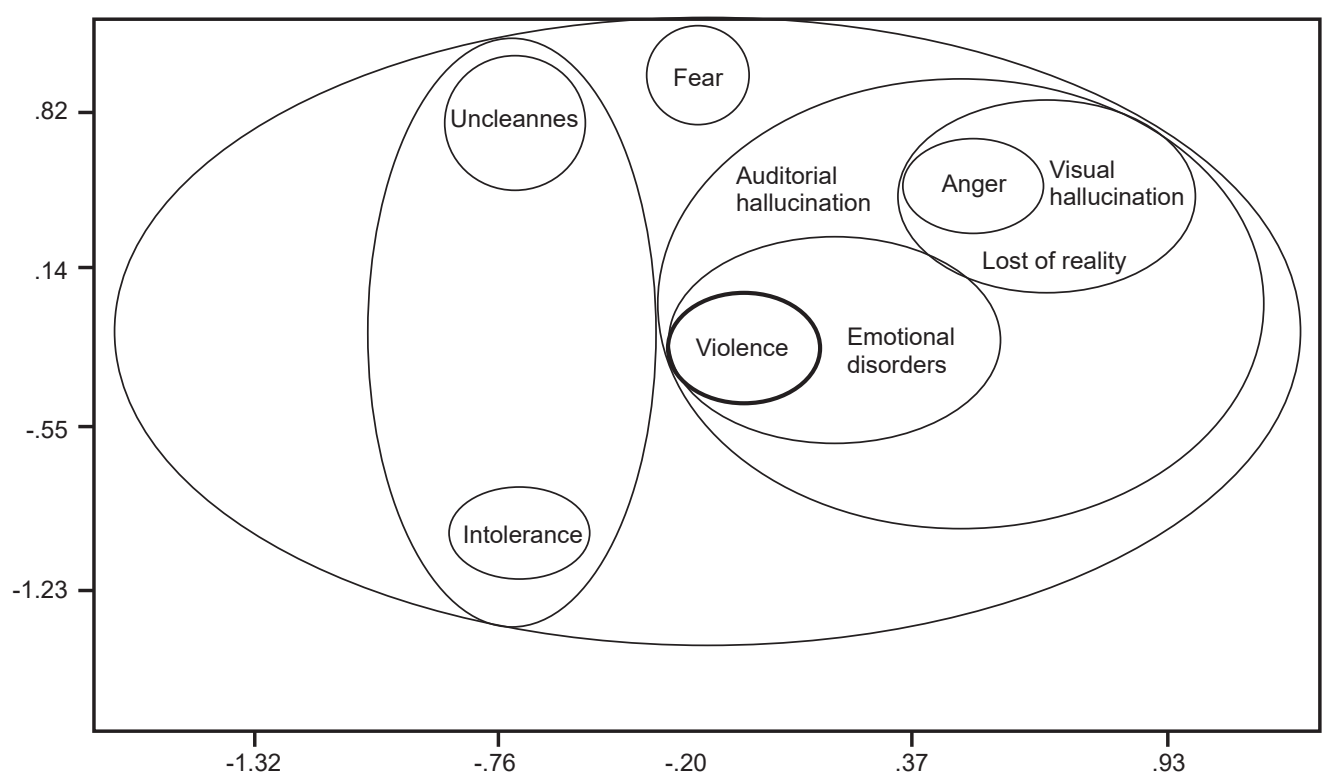

Figure 1. Multidimensional diagram. 
Table 4

Cultural competence y expressed emotion

\begin{tabular}{|c|c|c|c|c|c|}
\hline \multicolumn{3}{|c|}{ Adequate cultural competence } & \multicolumn{3}{|c|}{ Inadequate cultural competence } \\
\hline \# & Subject & Low EE total & \# & Subject & High EE total \\
\hline 1 & 2 & 38 & 1 & 1 & 72 \\
\hline 2 & 4 & 34 & 2 & 3 & 103 \\
\hline 3 & 6 & 34 & 3 & 8 & 112 \\
\hline 4 & 10 & 35 & 4 & 9 & 104 \\
\hline 5 & 21 & 82 & 5 & 12 & 109 \\
\hline 6 & 26 & 41 & 6 & 13 & 95 \\
\hline 7 & 29 & 60 & 7 & 15 & 104 \\
\hline 8 & 33 & 64 & 8 & 28 & 103 \\
\hline 9 & 35 & 60 & 9 & 31 & 103 \\
\hline 10 & 36 & 36 & 10 & 32 & 92 \\
\hline \multirow[t]{8}{*}{11} & 38 & 35 & 11 & 34 & 83 \\
\hline & & & 12 & 39 & 112 \\
\hline & & & 13 & 40 & 105 \\
\hline & Sum & 519 & & Sum & 1297 \\
\hline & Mean & 47.18 & & Mean & 99.77 \\
\hline & $\sigma 2$ & 271.56 & & $\sigma 2$ & 134.52 \\
\hline & SD & 16.48 & & SD & 11.60 \\
\hline & $n$ & 11 & & $n$ & 13 \\
\hline
\end{tabular}

mality, it was decided to transform the data obtained into natural logarithms. Then, the normality verification process was repeated with the variable transformed to the Napierian logarithm, which were also significant. Therefore, since the parametric verification of the normal distribution of the samples was not validated, the data was analyzed with the non-parametric method of the Mann-Whitney $U$ test as suggested by Martínez-González, Sánchez-Villegas, and Faulin (2006).

The Mann-Whitney $U$ test also suggested a lower statistical significance at $U=1.000, p<.001$, which confirmed that the best-informed relatives had less expressed emotion than those people who were less-informed about schizophrenia. Therefore, there is a significant association between the cultural agreement on the symptoms of schizophrenia and the emotion expressed in the relatives of people with schizophrenia from SALME. That is, there is a relation between cultural competence and expressed emotion.

\section{DISCUSSION AND CONCLUSION}

The design used in this research coincides with other articles in this area such as those by Aurioles Tapia \& Torres-López (2016), García de Alba-García et al. (2011), and Herrera-Suárez et al. (2008). In the same way, the sample of people calculated for this study was similar to the number of people that have been included in previous studies that worked with cultural agreements or expressed emotion, such as those by Guidorizzi, Ciccone, and Frari (2012), Chávez-Flores (2007), and Kuipers (1992). However, this study is inno- vative because there are no references to other research that addresses the issue of cultural agreement in schizophrenia, nor the relationship of symptoms of the schizophrenia concept with expressed emotion in relatives of people with this illness.

In relation to the symptoms of schizophrenia, scientifically, the ICD-10 and DSM-5 manuals recognize five basic types of symptoms (Morrison, 2008) associated with psychosis, in particular with schizophrenia: hallucinations, delusions, disorganized language, disorganized behavior, and negative symptoms. However, the cultural-social knowledge about the symptoms does not always have attachment to the academic reality studied.

For example, some investigations carried out in Spain have studied this issue (Ruiz et al., 2012) in more than 2,000 healthy people not related to this illness. In this study, it was shown that 1,010 of the people surveyed $(51 \%)$ were not able to mention any symptoms related to schizophrenia. In the same research, the auditory hallucinations occupied the first place of the mentions with $12.5 \%$. The symptom that followed was violent behavior with $9.7 \%$. Personality changes were mentioned in $6.2 \%$, paranoia in $4.6 \%$, change of humor $4 \%$, delusions in $3 \%$, and, to a lesser percentage, nervousness and stress.

In the present study, focused on relatives who had direct contact with people affected with this illness, and who had received informal education about this condition from various psychoeducational professionals, violence was identified as the main symptom of schizophrenia. This finding agrees with the data previously mentioned in the Ruiz et al. (2012) study, in which the variable "violence", occupied one of the firsts places among mentions, and concurs too with the study of Fernández-Consuegra and Fabelo-Mora (2003), in which violence was reported, by relatives and neighbors, as related with the appearance of schizophrenia.

The variables "intolerance" and "anger" were ranked at the fourth and fifth positions among mentions. These two concepts are highly related to violence too. It is worth mentioning that the primary caregivers of people with schizophrenia consider violence as the main symptom of this condition, when neither APA nor the WHO recognize it as part of the group of symptoms or diagnostic criteria. In this sense in Israel, Fleischman et al. (2014), suggest that violence should be recognized as part of the clinical picture of schizophrenia to manage its risk.

In contrast, Esbec Rodríguez and Echeburúa Odriozola (2016) claim that people with schizophrenia are not any more violent than the general population, as long as they are: under pharmacological control, have not been recently discharged from hospitalization, had good adherence to treatment, and have not used drugs. These authors mentioned that the stigmatization suffered by these people is attributed more to the conception of people with schizophrenia as unpredictable and dangerous persons (Casco, 
Natera, \& Herrejón, 1987; Thompson et al., 2002) than to a scientific reality.

Concerning stigma, Wahl and Harman (1989) found that family members of schizophrenia individuals, identified as the main source of stigma, the violence attributed to people with that illness coming from: murder films, newspapers tabloids that involves egregious deeds with mental disabilities with terms like "schizophrenic" or "psycho". Generally speaking, it is believed that people with schizophrenia end up being serial killers and people who should be feared. Even jokes about "insanity" alludes to these stigmas. In this regard, Esbec Rodríguez and Echeburúa Odriozola (2016), coincides with this argument arising from the "emphasis placed by the media on specific events carried out by a small percentage of these patients" (p. 70). Ruiz et al. (2012) stated that associating violence with schizophrenia individuals is a stigma or harmful myth in the social understanding of mental illness.

The debate about the association of violence with schizophrenia is complex, however, the Internationals Classifications Systems for Mental Illnesses (ICD-10 or DSM-5) do not understand it as a diagnostic criterion, although APA does indicate that violence is a factor that could be associated with this disorder. However, clarifies: "The vast majority of people with schizophrenia are not aggressive" (APA, 2004, p. 101), and that, contrary to popular belief, they tend to be more victims of violence than perpetrators, conclusion which also assisted Fernández-Consuegra and Fabelo-Mora (2003), study.

It is remarkable and perhaps understandable that society creates stereotypes around schizophrenia due to the misinformation and social stigmatization of mental disorders. But why do people closely related to the their relatives understand this manifestation as the central symptom of the illness? Feasibly, it should be assumed that being directly involved with a person with a mental disorder allows people to understand the reality of mental disorders in greater depth. According to Magliano et al. (2004), family members and mental health professionals are the most effective people in identifying schizophrenia ( $\geq 70 \%$ ), compared to the general population. However, familiarity or closeness does not exempt any individual from having a "deficient" understanding of these conditions or perhaps a more realistic one.

There are different ways of understanding this phenomenon, as with everything else. On the one hand, there is a knowledge based on the scientific information available; on the other, there is the knowledge coming from life experiences or encounters. It is likely that the family members of those who suffer from schizophrenia are more likely to highlight violence the given limited treatments available, difficulties in accessibility (costs, deficient number of professionals, allocation problems), and other variables associated with education, sociocultural marginalization and poverty, not to mention the deficient Latin American health system in general terms. These obstacles bring about different prognosis and evolution of schizophrenia in the people of Mexico and in Latin America, unlike other countries as the United States, European countries and even with better expectations in countries such as Japan or Hong Kong (APM \& APAL, 2014).

Therefore, violence and stigma in schizophrenia deserve a much more detailed study, because in some contexts it could be the reflection of a cultural misunderstanding. The scientific community should consider proposals like doctor Brian Koehler's, among others, who claims that the concept of "schizophrenia" should be abolished.

Regarding the other concepts that were part of the cultural agreement on this research, the symptom of auditory hallucinations occupied the second place of importance in the mentions. This coincides with what is proposed in the DSM-5 where this symptom is also described as: "the most common in schizophrenia and in disorders related to psychosis, which people with this disorder experience in the form of voices that are understood as different from the thinking of the patient" (APA, 2004, p. 87). This fact confirms the closeness of the understanding that relatives also have with one of the most notorious and prevalent scientific symptomatic facts in this population group. Finally, it is remarkable that delusions and negative symptoms are not part of the main mentions in this study and are located at the seventh place in cultural agreement in the sample under study. The fact that negative symptoms are not easily recognized is something quite common according to Leff and Vaughn (1985), which leads to them being one of the most important triggers for the appearance of critical and aggressive attitudes by family members, that is to say, of the appearance of the Expressed Emotion.

From the total of five possible symptoms of criterion for the diagnosis of schizophrenia, only two were literally mentioned: hallucinations (visual and auditory) and delusions, which are manifestations that occur in more than $90 \%$ of people with this diagnosis. The olfactory, gustatory or tactile were not mentioned, which are statistically less frequent (APA, 2004), even since the prehistory of the epistemological paradigm of the use of the word "hallucination" as a phenomenon of the distant senses (Berrios, 2008). The other three primary symptoms of diagnostic criteria that weren't mentioned: language and disorganized behavior.

The significant relationship found with the Mann-Whitney $U$ test between cultural consensus and expressed emotionality supports what is stated in the theory. The less adequate cultural competence (bad informants), the greater expressed emotion, which is translated into hostility and over-involvement to the patient. It is important to reinforce psychoeducational strategies that influence forging better-informed individuals and therefore with a lower production of hostility and over-involvement that bring with them 
more prone relapses on the part of patients and a worse prognosis.

Associating violence with schizophrenia is part of a harmful myth in the social understanding of mental illness. A significant difference was found between relatives who had a better knowledge about schizophrenia, who expressed low EE, as opposed to those who showed greater ignorance and expressed high EE. Violence was identified as one of the main symptoms of schizophrenia according to the valid cultural agreement on this study. This may be related to the poor understanding of the disease, stigma and the reality of the outcomes of people with schizophrenia in Latin America unlike other countries due to restricted access to mental health care, medicines and poverty.

Psychoeducational interventions should be carried out for users and their families on their own environments, which would allow all of them to have a better understanding of the disease and reduce the high expressed emotion and stigma. This finding may contribute to a better understanding of factors related to culture and family environments, which in could turn influence the course of schizophrenia. Further studies should cover larger populations of relatives from different parts of Mexico and use anthropological methods to increase the understanding about the symptoms of this disease and compare the data with those of other countries.

Therefore, it should be opportune to review a term that in more than 110 years has not changed as has been the case with other psychopathologies. Etymologically, the term schizophrenia describes an imprecision currently evidenced by scientific advances, and is full of stigmas that exclude, defame, and violate the lives of people with this stigmatizing diagnosis, who have been invisible for more than a century.

\section{Funding}

None.

\section{Conflict of interest}

The authors declare they have no conflicts of interest.

\section{Acknowledgments}

We would like to thank the authorities from Instituto Jalisciense de Salud Mental and their community of users and their families. Also, we are grateful with the students of the Psychology Career from Centro Universitario de Ciencias de la Salud de la Universidad de Guadalajara.

\section{REFERENCES}

Asociación Psiquiátrica Americana [APA]. (2004). Manual Diagnóstico y Estadístico

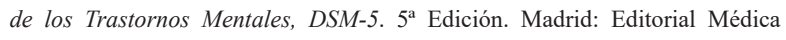
Panamericana. ISBN 9788491103721

Asociación Psiquiátrica Mexicana [APM]. (Eds.). (2014). Consenso Nacional y Guía de Práctica Clínica de la Asociación Psiquiátrica Mexicana y de la Asociación Psiquiátrica de América Latina para el tratamiento de las personas con esquizofrenia. Guía basada en la evidencia de la APAL y de la APM para el tratamiento de la esquizofrenia, Salud Mental, 37(Suppl 1). Retrieved from http://www.scielo.org.mx/pdf/sm/v37s1/v37s1a1.pdf

Asociación Psiquiátrica Mexicana, \& Asociación Psiquiátrica de América Latina [APM \& APAL]. (2014). Consenso Nacional y Guía de Práctica Clínica de la Asociación Psiquiátrica Mexicana y de la Asociación Psiquiátrica de América Latina para el tratamiento de las personas con esquizofrenia: IV. Aspectos transculturales de la esquizofrenia. Salud Mental, 37(Suppl 1), 85-90.

Aurioles Tapia, I., \& Torres-López, T. (2016). Dimensiones culturales sobre seguridad y salud ocupacional de trabajadoresdeunaempresa de manufactura prefarmacéutica. Psicogente, 19(36), 206-216. doi: 10.17081/psico.19.36.1292

Barrowclough, C., Tarrier, N., Humphreys, L., Ward, J., Gregg, L., \& Andrews, B. (2003). Self-esteem in schizophrenia: Relationships between self-evaluation, family attitudes, and symptomatology. Journal Abnormal Psychology, 112(1), 92-99. doi: 10.1037/0021-843X.112.1.92

Berrios, G. E. (2008). Historia de los sintomas de los trastornos mentales. La psicopatología descriptiva desde el siglo XIX. Ciudad de México: Fondo de Cultura Económica. ISBN 978-968-16-8299-6

Borgatti, S. P. (1994). Cultural Domain Analysis. Journal of Quantitative Anthropology, 4, 261-278.

Casco, M., Natera, G., \& Herrejón, M. E. (1987). La actitud hacia la enfermedad mental, una revisión de la bibliografía. Salud Mental V, 10(2), 41-53.

Chávez-Flores, A. (2007). Valores predictivos de gravedad en un grupo de pacientes con trastornos de la conducta alimentaria. Acta Médica Grupo Ángeles, 5(3), 123-128.

Clark, L., Vojir, C. P., Hester, N. O., Foster, R., \& Miller, K. L. (1998). MDS and QAP: How do children rate painful experiences? In V. C. de Munck, E. J. Sobo (Eds.). Using methods in the field: A practical introduction and casebook. California: Altamira Press. ISBN 978-0761989134

De la Higuera, J. (2005). Psicoeducación familiar en la esquizofrenia: de los datos empíricos a la realidad clínica. Apuntes de Psicología, 23(3), 275-292.

De la Torre Vera, N. L. (2018). Emoción expresada familiar en tutores responsables y problemas de conducta agresiva y delictiva en adolescentes del servicio de orientación al adolescente de la ciudad de Arequipa (Tesis de licenciatura). Universidad Católica San Pablo, Arequipa, Perú.

Esbec Rodríguez, E., \& Echeburúa Odriozola, E. (2016). Violencia y esquizofrenia: un análisis clínico-forense. Anuario de Psicología Jurídica, 26(1), 70-79. doi: 10.1016/j.apj.2015.12.001

Fernández-Consuegra, M. L., \& Fabelo-Mora, V.A. (2003). Violencia y esquizofrenia, ¿víctimas o victimarios? Rev Cubana Med Gen Integr, 19(5), 1-7.

Fleischman, A., Werbeloff, N., Yoffe, R., Davidson, M., \& Weiser, M. (2014). Schizophrenia and violent crime: a population-based study. Psychological Medicine, 4(1), 3051-3057. doi: 10.1017/S0033291714000695

Fleisher, M. S., \& Harrington, J. A. (1998). Freelisting: Managment at a woman federal prision camp. In V. C. de Munck, E. J. Sobo (Eds.). Using methods in the field: A practical introduction and casebook. California: Altamira Press. ISBN 978-0761989134

García de Alba-García, J. E., Quintanilla-Montoya, R., Sánchez-Loyo, L. M., MorfínLópez, T., \& Cruz-Gaitán, J. I. (2011). Consenso Cultural sobre el Intento de Suicidio en Adolescentes. Revista Colombiana de Psicología, 20(2), 167-179.

García de Alba-García, J. E., Salcedo-Rocha, A. L., Hayes, D., \& Milke, M. E. (2015). Dominio cultural sobre causas de diabetes en tres generaciones de estratos populares en Guadalajara, México. Rev Med Inst Mex Seguro Soc, 53(3), 308-315.

García-Sílberman, S. (2002). Un modelo explicativo de la conducta hacia la enfermedad mental. Salud Publica Mex, 44(4), 289-296.

Guanilo, J. V., \& Seclén, Y. M. (1993). Relación entre el nivel de conocimientos sobre enfermedad mental y el nivel de emoción expresada de los familiares de pacientes esquizofrénicos de consultorios externos del INSM HD-HN (Tesis de licenciatura). Universidad Nacional Mayor de San Marcos, Facultad de Medicina, Lima, Perú.

Guidorizzi, A. C., Ciccone, B. C., \& Frari, S. A. (2012). Adaptação cultural do Family Questionnarie para avaliação da emoção expressada. Enfermagem UERJ, 20(1), 90-97.

Gutiérrez, V. H. (2011). Diseño de un sistema de vigilancia para la esquizofrenia e 
los servicios de atención psiquiátrica (Tesis de maestría). Instituto Nacional de Salud Pública, Ciudad de México, México.

Heinze, G., Sheehan, D., \& Cortés, J. (2000). Mini International Neuropsychiatric Interview (MINI): Spanish version (South and Central America). México, DF: Instituto Nacional de Psiquiatría Ramón de la Fuente Muñiz.

Herrera-Suárez, C. C., García-De Alba, J. E., Vásquez-Garibay, E. M., RomeroVelarde, E., Romo-Huerta, H. P., \& Troyo-Sanromán, R. (2008). Consenso Cultural sobre Alimentos en Adolescentes Embarazadas de Guadalajara, México. Rev Salud Pública, 10(5), 723-731.

Jenkins, J. H. (1991). Anthropology, Expressed Emotion, and Schizophrenia. Ethos, 19(4), 387-431. doi: 10.1525/eth.1991.19.4.02a00010

Kuipers, L. (1992). Expressed emotion research in Europe. Br J Clin Psychol, 31(4), 429-443. doi: 10.1111/j.2044-8260.1992.tb01017.x

Leff, J., \& Vaughn, C. (1985). Expressed Emotion in Families: Its Significance for Mental Illness. New York: Guilford Press. ISBN 978-0898620580

Magliano, L., De Rosa, C., Fiorillo, A., Malangone, C., Guarneri, M., \& Marasco, C. (2004). Beliefs of psychiatric nurses about schizophrenia: A comparison with patient'srelatives and psychiatrists. International Journal of Social Psychiatry, 50(4), 319-330. doi: 10.1177/0020764004046073

Martínez-González, M. A., Sánchez-Villegas, A., \& Faulin, J. (2006). Bioestadística amigable. 2a Edición. Madrid: Díaz de Santos. ISBN 84-7978-791-0

Morrison, J. R. (2008). DSM - Guía para el diagnóstico clínico. México: Editorial El Manual Moderno. ISBN 978-970-729-301-4

Ochoa, S., Martínez, F., Ribas, M., García-Franco, M., López, E., Villellas, R., ... Haro, J. M. (2011). Estudio cualitativo sobre la autopercepción del estigma social en personas con esquizofrenia. Revista de la Asociación Española de Neuropsiquiatría, 31(111), 477-489.

Phillips, M. R., Pearson, V., Li, F., Xu, M., \& Yang, L. (2002). Stigma and expressed emotion: a study of people with schizophrenia and their family members in China. Br J Psychiatry, 181, 488-493. doi: 10.1192/bjp.181.6.488

Rascón, M. L., Gutiérrez, M. L., Valencia, M., \& Murow, E. (2008). Relación entre la emoción expresada por el familiar responsable y la conducta sintomática de pacientes con esquizofrenia, incluido el funcionamiento social. Salud Mental, $31(3), 205-212$.
Rosas-Santiago, F. J. (2016). Estudios sobre la enfermedad Mental Crónica: Una revisión. Salud y Administración, 4(9), 25-30.

Rosenfarb, I., Nuechterlein, K., Goldstein, M., \& Subotnik, K. (2000). Neurocognitive vulnerability, interpersonal criticism, and the emergence of unusual thinking by schizophrenic patients during family transactions. Archives of General Psychiatry, 57(12), 1174-1179. doi: 10.1001/archpsyc.57.12.1174

Ross, G. (1998). Pile Sorting: "Kids Like Candy”. In V. C. de Munck, E. J. Sobo. Using methods in the field: A practical introduction and casebook (pp. 97-110). California: Altamira Press. ISBN 978-0761989134

Ruiz, M. A., Montes, J. M., Correas, J., Álvarez, C., Mauriño, J., \& de Dios, C. (2012). Opiniones y creencias sobre las enfermedades mentales graves (esquizofrenia y trastorno bipolar) en la sociedad española. Rev Psiquiatr Salud Ment, 5(2), 98-106.

Schaffhauser, P. (2010). La dicotomía emic/etic. Historia de una confusión. Relaciones: Estudios de Historia y Sociedad (Zamora), 31(121), 257-269. Retrieved from http://www.scielo.org.mx/scielo.php?script=sci_arttext\&pid $=$ S0185-39292010000100009

Secretaría de Salud. (1987). Reglamento de la ley general de salud en materia de investigación para la salud. Diario Oficial de la Federación.

Sellwood, W., Tarrier, N., Quinn, J., \& Barrowclough, C. (2003). The family and compliance in schizophrenia: the influence of clinical variables, relatives' knowledge and expressed emotion. Psychological Medicine, 33(1), 91-96. doi: $10.1017 / \mathrm{s} 0033291702006888$

Thompson, A. H., Stuart, H., Bland, R. C., Arboleda-Florez, J., Warner, R., Dickson, R. A., ... Wing, N. N. (2002). Atittudes about schizophrenia from the pilot site of the WPA worldwide campaign against the stigma of schizophrenia. Social Psychiatry and Psychiatric Epidemiology, 37(10), 475-482. doi: 10.1007/ s00127-002-0583-2

Wahl, O. F., \& Harman, C. R. (1989). Family views of stigma. Schizophrenia Bulletin, 15(1), 131-139. doi: 10.1093/schbul/15.1.131

Weller, S. C., \& Romney, A. K. (1998). Systematic data collection. Qualitative Research Methods. California: Sage Publications. ISBN 978-0803930742

World Health Organization [WHO]. (2019). Esquizofrenia. Retrieved from https:// www.who.int/news-room/fact-sheets/detail/schizophrenia 